\title{
RETURNING LOOTED EUROPEAN LIBRARY COLLECTIONS: AN HISTORICAL ANALYSIS OF THE OFFENBACH ARCHIVAL DEPOT, 1945-1948
}

In 1944, Pierce Butler wrote, "ever since libraries have existed, war has been one of the chief agencies of [their] annihilation." 2 The looting and destruction of cultural treasures during wartime is an established fact throughout Western history, including Greek and Roman times as well as during the Crusades, when empires stripped defeated nations of their cultural heritage. During the Napoleonic Wars in the early nineteenth century, Napoleon had an army of art commissioners who were ordered to locate and seize valuable cultural property, including whole libraries, for transfer to France. But the systematic Nazi confiscation of European cultural treasures in the twentieth century was unique, as looting attained new ideological and methodological dimensions that furthered the Nazi goals of destroying whole peoples and cultures.

Despite recent publicity on the restitution of Nazi stolen artworks, the seizure and destruction of European library collections receives little attention today. But this was certainly not the case just after the end of the war. Recognizing the massive looting that had transpired, the Allies set up the largest book restitution program in history, a program that can justly be described as the antithesis to the German plundering machine. In March 1946, the Allied Military occupation government of Germany established the Offenbach Archival Depot, and placed it under the supervision of the Monuments, Fine Arts, \& Archives program (MFA\&A), a branch of the Office of Military Government in Germany and Austria. The task of the men assigned to the program-young historians, museum curators, librarians, and archivists-was to recover,

1. The views expressed in this essay are those of the author and do not necessarily reflect the views or policies of the History of Medicine Division, National Library of Medicine.

2. Pierce Butler, ed. Books and Libraries in Wartime (Chicago: Univ. of Chicago Pr., 1945), 14. 
identify, and restore stolen cultural property to its country of origin, including library and manuscript collections, and Judaic- related materials. By the time the Depot closed in 1949, it had handled more than 3.2 million items in over thirty-five languages and more than 2.8 million were returned to over fourteen nations. ${ }^{3}$ This essay explores the origins of the Offenbach Depot, the role of the MFA\&A in the recovery and restitution of library and manuscript collections (particularly Judaica), and the question of "heirless" and "unidentifiable" Nazi loot being housed in American library collections.

Soon after their rise to power in 1933, the Nazis began to purge more than sixteen thousand pieces of so-called "degenerate art" (Entartete Kunst) from German public institutions. Degenerate art included any type of modern or abstract art that was unacceptable to the Reich, or as the Nazis called it "un-German": cubism, expressionism, impressionism, and surrealism. Books deemed un-German included antigovernment literature, and religious, philosophical, and theological treatises. By 1938, the Nazi Party declared that all German art museums had been purified, including the Nazi confiscations of books and manuscript collections. Joseph Goebbels, Hitler's Reichsminister für Volksaufklärung und Propaganda (Reich Minister for Public Enlightenment and Propaganda), directed the purging of modern artworks and books from all German public institutions.

Through its Arbeitsgruppen and Sonderkommandos, the Nazis systemically stole an unknown, but very large, number of books, manuscripts, and religious items from Jewish institutions and communities in cities including Berlin, Warsaw, Paris, Vilnius, and Vienna. This can be viewed as a deliberate effort to rid Germany and Europe of Jewish culture.

Religious items and metals from bookbindings were melted, while thousands of books were disposed of or burned. State-mandated Nazi plundering in the east began in 1939 in Poland, and, in 1940, the Nazis and their German collaborators moved westward, beginning in the Netherlands and France. Looting in the west fell under the direction of Nazi ideologue and ardent anti-Semite Alfred Rosenberg's Paris-based operation, the Einsatzstab Reichsleiter Rosenberg (ERR), which aligned

3. MFA\&A files are located in the Ardelia Hall Collection, Records of the Collecting Points, Records of the U.S. Occupation Headquarters, World War II, RG 260, and the Records of the American Commission for the Protection and Salvage of Artistic and Historic Monuments in War Areas ("The Roberts Commission"), RG 239, National Archives at College Park, MD (NACP). 
itself with the Wehrmacht in order to receive police protection while it looted. In 1941, Hitler ordered Rosenberg to establish the Institut zur Erforschung der Judenfrage (Institute for the Research of the Jewish Question) in Frankfurt in order to wage an "ideological and spiritual war against Jews and Judaism."4

Books and manuscript collections stolen by the ERR were divided among German institutions, including Rosenberg's institute and other Nazi libraries, for so-called "scholarly" purposes. By 1944, the ERR would confiscate more than two hundred Jewish collections, approximately 21,000 objects, and more than three million books from over a thousand libraries. ${ }^{5}$ Ironically, the Nazis also saved millions of books. These items went to Nazi-sponsored research institutes and social and political research centers as part of a program to acquire information on religious and ethnic groups slated for extermination and "to provide a pseudo scientific basis for the virulent anti-Semitic propaganda." ${ }^{6}$ Most of the books remained in Frankfurt during the war. In 1944-1945, Allied bombings forced the Institut to evacuate the materials to Hungen, a mine outside Frankfurt. The swift relocation forced the Nazis to toss the books into storehouses without indication as to the origin of materials. Once found, the books themselves would reveal their respective institutions and private collectors, including Bibliotheca Rosenthaliana, the Spinoza, Rothschild, YIVO, Collegio Rabbinico Italiano, and the Portuguese-Jewish Seminary.

The Roberts Commission, a U.S. government-appointed group, established the Monuments, Fine Arts, and Archives (MFA\&A) program in 1943 and charged it with protecting cultural treasures in European war zones. In summer 1943, MFA\&A officers began working with Allied military commanders in Italy to identify cultural materials in war-torn areas. ${ }^{7}$ The MFA\&A's greatest challenge was preventing Allied troops

4. Michael Dobbs, "Nazi Loot May Line American Shelves," Washington Post, 5 January 2000, C1+.

5. Einsatzstab Reichsleiter Rosenberg (ERR) Card File, 1940-1945, ed. Anne Rothfeld (National Archives Microfilm Publication, M1943). See Leslie I. Poste, "Books Go Home from the Wars," Library Journal (Dec. 1, 1948): 1699, 1701.

6. Robert G. Waite, "Returning Jewish Cultural Property:The Handling of Books Looted by the Nazis in the American Zone of Occupation, 1945 to 1952," Libraries \& Culture 37, no. 3 (2002): 213-28.

7. Named after Supreme Court Justice Owen J. Roberts, the commission's full name is the American Commission for the Protection and Salvage of Artistic and Historical Monuments in War Areas. President Roosevelt authorized it to promote the protection and recovery of stolen art provided that it did not interfere with military operations. See Lynn H. Nicholas, The Rape of Europa:The Fate of Europe's Treasures in the Third Reich and the Second World War (New York:Vintage, 1995). 
from stealing books and artworks and sending them home to the States. Another challenge was managing so-called lost-and-found warehouses of stolen European cultural property, especially after 1945 as civilians arrived to claim their respective materials. These temporary facilities at Munich, Wiesbaden, Marburg, and Offenbach became known as the Allied collecting points and each had its own restitution specialty. ${ }^{8}$ Beginning in 1945 and continuing into 1947, Allied troops and MFA\&A officers implemented the large-scale program of moving more than four million objects to one of the four collecting points.

Beginning in spring 1945, Allied troops and the MFA\&A discovered hundreds of caves and mines, an estimated 1,500 hidden repositories, that stored Nazi caches. Finds included paintings at Siegen in Westphalia (Germany), millions of Reichmarks and gold bars at Merkers (Germany), and more than 6,500 paintings for Hitler's Linz Museum at Alt Aussee (Austria). ${ }^{9}$ Both the Property Division of the Office of Military Government for Germany, U.S. Zone (OMGUS), and the U.S. Allied Commission for Austria (USACA) administered the recovery and restitution efforts at the collecting points and served as immediate safe storage. The Third U.S. Army made an important discovery at the Hungen mine: not only were the Institut's contents hidden, but also ERR records, Nazi documents and propaganda materials, and artworks. Placed under U.S. military guard, the MFA\&A began transferring the items to the Rothschild Library in Frankfurt for further inspection. Despite its crowded surroundings, the library served as a storehouse for loot found in Greater Hesse. By the fall of 1945, with approximately twelve civilian staff members working in the library, the MFA\&A estimated that more than a million books from six different Hungen repositories arrived at the library, approximately 50,000 belonging to the Institut. ${ }^{10}$ However, barely 30,000 items had been identified. With trucks of newly discovered loot arriving daily, staff soon realized that sorting and cataloging

8. Marburg was open for a few months in 1945. Its contents were shipped to the other three collecting points. Munich was assigned materials needing restitution to foreign countries and the Bavarian State Museum. Wiesbaden was assigned German-owned materials from the former Prussian State Museums. Offenbach was assigned Jewish manuscript and religious items, library and archival collections.

9. MFA\&A Field Reports, entry 62, rolls 65-84, Records of the American Commission for the Protection and Salvage of Artistic and Historic Monuments in War Areas ("The Roberts Commission"), (National Archives Microfilm Publication M1944). See Nicholas, 328-31 and 34650 .

10. Leslie I. Poste, "The Development of U.S. Protection of Libraries and Archives in Europe during World War II" (Ph.D. diss., Univ. of Chicago, 1958), 336. See Anne Rothfeld, "Nazi Looted Art:The Holocaust Records Preservation Project," Prologue: Quarterly of the National Archives and Records Administration 34, no. 2 (2002): 127-39. 
at the rate of three hundred items per day would require more than twenty years to process the estimated two million books, assuming that the U.S. Army found no additional items. In October, at the recommendation of Leslie I. Poste, an MFA\&A officer, detailed cataloging ceased and the library moved to a larger facility across the river in Offenbach. Throughout the winter of 1945-1946, newly found books arrived daily and the identification of materials moved slowly. However, by February, despite receiving more than million items, no books had yet been returned to the country from which they had been taken.

The new facility for the restitution operation in Offenbach was a bombed-out five-story reinforced concrete plant that had belonged to the Internationale Geselischaft Farbenindustris A.G. (I. G. Farben). Staff were immediately confronted with the challenges of refurbishing the plant for the Depot's storage and office spaces. Initially, the building had no heat, no running water, no electricity, and almost all of the windows had been blown out from Allied bombardments. The roof and eaves leaked from the weight of sandbags and antiaircraft guns. The plant was not ready to either receive or house the war booty. However, the books and Judaica arrived daily as U.S. troops and MFA\&A renovated, weatherproofed, and secured the building.

In late February 1946, U.S. occupation government officials named U.S. Army Captain and MFA\&A Officer Seymour Pomrenze director of the Offenbach Archival Depot. Pomrenze, an archives expert and linguist, arrived at the Depot and found the Farben building in a deplorable state and the restitution operations severely understaffed. On March 2, 1946, the U.S. Office of Military Government (OMGUS) for Greater Hesse officially established the Depot as the sole body to return books. Furthermore, the March directive declared the Depot the "first priority of the MFA\&A restitution efforts."11 Pomrenze's position also authorized him to establish liaisons with Allied restitution officers; to supervise the depot's administrative needs including personnel, security, and transportation; and to decide on the disposition of materials with unknown origins. ${ }^{12}$ During the renovations, Pomrenze authorized the Farben plant to be outfitted with numerous sorting and storage rooms, a conserva-

11. "Establishment of the Offenbach Archival Depot" from Robert Wallach, 2 March 1946,Administrative Records, roll 1, Records Concerning the Central Collecting Points ("Ardelia Hall Collection”): Offenbach Archival Depot, 1946-1951, ed. Anne Rothfeld (National Archives Microfilm Publication M1942).

12. Ibid. 
tion lab, and a photographic studio. Security from both vandalism and theft remained the Depot's highest priority. Offenbach needed both protection and security while it held the discovered loot. ${ }^{13}$

As previously mentioned, the Depot's staff initially was instructed to provide detailed cataloging of books and Judaica, yet this only allowed for the identification of several hundred items. The Offenbach operation was always understaffed, forcing the MFA\&A to rely on denazified German civilians. However, much of the depot's success in its restitution efforts was due to a sorting and identifying procedure created by Pomrenze and further refined by his successor, Captain Isaac Bencowitz. Pomrenze returned to the United States in May 1946 to resume his duties at the National Archives, and Bencowitz, a chemist and expert in eastern European languages, became the Depot's second director. ${ }^{14}$ With approval from OMGUS, between May and November 1946, Bencowitz increased the Depot's staff to about two hundred, which included de-Nazified Germans and displaced persons, and created almost a dozen sorting teams that returned more than 2.3 million books and 225,000 religious pieces and manuscripts. ${ }^{15}$

Bencowitz realized that many books contained bookplates, markings, or stamps of known public repositories and private collections; others had no identifiable markings. Because no complete inventory or list existed and a system of identifying ownership marks in languages other than German was needed, Bencowitz had a staff member photograph the stamps and bookplates, index the photographs by country, and place them in albums titled "Ex Libris" to assist in the identification of rightful owners. Each unique stamp was given a number, and sorters could compare the plates of the unidentifiable books to those in the albums. By the time Bencowitz left Offenbach in November 1946, he had perfected the sorting procedures so extensively that only approximately 878,000 items remained awaiting restitution. More important, after eighteen months of operation with limited supplies and staff, the MFA\&A returned more than 2.5 million items. ${ }^{16}$

13. Monthly Activity Reports, March 1946-August 1947, rolls 9 and 10, M1942, NACP.

14. U.S. personnel assigned to direct the depot following Bencowitz's departure in November 1946 included Theodore Heinrich (November 1946-January 1947), Joseph Horne (1947-48), and James Kimball (February-April 1949).

15. Seymour J. Pomrenze, "The Restitution of Jewish Cultural Treasures after the Holocaust," Rosaline and Meyer Feinstein Lecture Series, June 2002.

16. Monthly Activity Reports, rolls 9 and 10, M1942, NACP. By the time the depot closed in 1949 , more than four thousand library markings would appear in the albums: about 2,200 from Eastern Europe and about 1,700 from Western Europe. Photographs of "Ex Libris" Library Bookplates, taken by the Offenbach Archival Depot, ca. 1946, albums I-II, roll 11, M1942, NACP. 
Bencowitz's sorting procedures ran as follows: first, crated books were triaged into identifiable and unsorted items. Clearly identifiable items were grouped by book markings, inventoried, and shipped to their country of origin. Next, the unsorted items were divided by language or country. Staff checked these unsorted items against book markings in the "Ex Libris" albums. Last, the unidentified items were carefully researched for bibliographic and subject information, which often required the expertise of Hebrew and Slavic linguists.

As Pomrenze concentrated on establishing the Depot and as books continued to arrive, Luther Evans, the librarian of Congress, sent a group headed by David Clift to Germany. Their mission was to purchase German- and Nazi-published books and newspapers, and publications that were owned or created by the Nazi Party and its official agencies, then distribute the ownerless materials to American libraries, including the Library of Congress. ${ }^{17}$ The newly formed Library of Congress Mission (LCM) was to remove and preserve Nazi materials such as those found in Rosenberg's institute before they were destroyed by Germans or Allied troops. To carry out this plan, the LCM cooperated with the Depot's Liaison Branch in creating an agreement "whereby all materials subject to confiscation because they actually had been owned or created by the Nazi Party or its official agencies were to be delivered to the Library of Congress Mission." ${ }^{18}$ Administrators of both the Depot and the Library of Congress instructed members of the LCM to stay away from MFA\&A restitution operations at Offenbach and not to bring any "restitutable" materials into the Library's collections for fear that the rightful owner could make a claim in the near future.

On March 21, 1946, OMGUS, the U.S. occupation government, authorized the first of many shipments to the Library of Congress: 4,712 items, consisting mainly of Nazi-published items from Rosenberg's Institut der NSDAP zur Erforschung der Judenfrage. Pomrenze signed the receipt stating that Offenbach officials acknowledged the transfer of materials conformed to the agreements and that the shipment included mate-

\footnotetext{
17. "Agreements Negotiated by the Commission in the Public and Private Sectors" and "Heirless Assets and the Role of Jewish Cultural Reconstruction, Inc.," Presidential Advisory Commission on Holocaust Assets in the U.S. Plunder and Restitution:The United States and Holocaust Victims Assets: Findings and Recommendations of the Presidential Advisory Commission on Holocaust Assets in the U.S. and Staff Reports (Washington, D.C.: 2000) (hereafter PCHA). Report is available at the PCHA home page at http://www.pcha.gov/PlunderRestitution.html/html/Home_Contents.html.

18. Poste, "The Development of U.S. Protection of Libraries and Archives," 345-46.
} 
rial from the Institut but did "not include material confiscated by the NSDAP from countries other than Germany which would be subject to normal restitution procedures." 19 The Library of Congress continued to receive items, totaling approximately 19,000 volumes, until the Depot closed in 1949. Unfortunately, an inventory does not survive.

From 1946 to 1949, the Depot continued to return hundreds of thousands of items, and the numbers listed in its monthly reports describe the history of its operations and reflect the magnitude of the MFA\&A's work. The first shipment of books that left the Depot for the Netherlands consisted of 371 crates, or approximately 78,000 items. At the same time, 730 crates containing approximately 153,000 items were sent to France. And soon after, the Depot transported 700,000 items in twenty-three freight cars to the Prussian State Library in Berlin. ${ }^{20}$ The staff worked under constant pressure to identify as many items as possible, and the Depot seemed to have had an atmosphere of constant emergency measures compounded with the urgency of quickly finishing its work. In February 1949, the MFA\&A began transferring approximately 500,000 of the Jewish books and religious items that remained unidentified to the Jewish Cultural Reconstruction organization (JCR) for distribution to European and American Jewish communities to perpetuate Jewish art and culture. Located in New York City, the JCR distributed books, torah scrolls, prayer shawls, Jewish ritual objects containing precious metals and stones, as well as paintings and furniture to Jewish cultural, educational, and religious institutions. The distribution method reportedly used by JCR went as follows: numerous librarians combed through the JCR warehouse, selecting items appropriate for their respective collections. Approximately 158,000 items went to American libraries, including the Library of Congress, Baltimore Hebrew University, Harvard University, Johns Hopkins University, New York University, University of Iowa, Brandeis University, and the Jewish Institute of Religion. Unfortunately, lists of what the librarians acquired do not survive. ${ }^{21}$ In May 1949, OMGUS transferred nonmilitary opera-

19. "Receipt for 4712 items transferred to the LC Mission," 21 March 1946, from Pomrenze to OMGUS,Administrative Records, roll 1, M1942, NACP. Inventory reads "a. 29 cartons (card board) 1500 books, b. 5 cases (wooden) Periodical Weltkempf, c. 27 cartons (card board) Miscellaneous German Newspapers and Magazines."

20. By my estimates, one crate $=\sim 20$ items; $\sim 146$ crates $=$ one railway car. These numbers are taken from the Depot's monthly reports. Monthly Activity Reports, rolls 9 and 10, M1942, NACP. 21. "Agreements Negotiated by the Commission in the Public and Private Sectors" and "Heirless Assets and the Role of Jewish Cultural Reconstruction, Inc.," PCHA. See Michael Grunberger, "Special Challenges in Dealing with Looted Book Collections," Vilnius International Forum on Holocaust Era Looted Cultural Assets, 2000. Report is available at http://www.vilniusforum.lt/. 
tions to the U.S. State Department. ${ }^{22}$ Offenbach began closing down operations, and its remaining items were transferred to the Wiesbaden Collecting Point. Restitution by the MFA\&A at Wiesbaden continued until 1951.

From the 1950s to the 1990s, a "long silence" ensued over the issue of locating confiscated assets; even today, there remains uncertainty about how many books, artworks, and other assets remain missing. In the mid-1990s, among the news of unclaimed Swiss banking accounts and plundered artworks hanging in renowned art galleries, an allegation was made that the Library of Congress's European Mission improperly acquired Nazi-looted Jewish books before the MFA\&A was able to make restitution. The Justice Department's Office of Special Investigations (OSI) led an investigation to determine if this was true. OSI investigators examined the MFA\&A archival records at the National Archives and the Library's European Mission and Cooperative Acquisition Project in the Library's Manuscript Division and issued its report in 1999, concluding that the LCM and the Depot acted appropriately. ${ }^{23}$ Because there was no clear evidence of rightful ownership, the MFA\&A could not have made restitution on the questionable items. The Depot shipped the materials only after approval and clearance from General Clay, the deputy military governor of the U.S. occupation zone. Furthermore, the report reinforced that the LCM primarily received materials published, rather than stolen, by the Nazis, which the military occupation government would have destroyed had the LCM not acquired them. In sum, the LCM functioned both legally and ethically.

However, it is commonly acknowledged that many of the looted books are in American library collections. In a postwar interview, Pomrenze stated that the Depot's staff found it "impossible to completely separate the looted from the non-looted material" and "many of the books bore no marks that would permit sorters to identify owners." ${ }^{24}$ Moreover, the recipient libraries did not separate the JCR books from the regular collection. So, how could a library such as the Library of Congress clearly

22. Effective June 6, the Office of the U.S. High Commissioner Germany (HICOG) governed Germany.

23. "Agreements Negotiated by the Commission in the Public and Private Sectors" and "Heirless Assets and the Role of Jewish Cultural Reconstruction, Inc., PCHA. See "Library of Congress Acquisitions in Post-War Germany," prepared by Stuart D. Goldman (24 November 1999), The Jewish Virtual Library.Available online at http://www.jewishvirtuallibrary.org/jsource/index. html. [Accessed January 2004].

24. Dobbs, $\mathrm{C} 1+$. 
identify items in its collection believed to be stolen, especially when no itemized shipping and receiving lists exists. Unlike paintings, books traditionally have no bills of sale to show provenance. Is a bibliographic note suitable? If so, what could be stated without causing controversy and embroiling one's institution in a potential lawsuit?

In 1999, the Presidential Advisory Commission on Holocaust Assets (PCHA) contacted the Library of Congress regarding allegations that the Library's holdings included looted books that had been distributed by the JCR. The PCHA and the Library analyzed a sample of its Hebraic collection and found items bearing bookplates from JCR and various European Jewish collections. ${ }^{25}$ These items included rabbinic texts, prayer books, and Yiddish literature. Due to these discoveries and desiring full disclosure of the materials, the Library of Congress created a virtual library identifying the books and their full provenance. The collection description reads as follows:

Between 1949 and 1952, the Library of Congress received 5,708 books, pamphlets, periodicals, and newspaper items from [the] Jewish Cultural Reconstruction (JCR) ... By agreement, JCR received these "heirless" and "unidentifiable" books from the United States Military Government in Germany ... JCR subsequently distributed almost 500,000 of these orphaned books to scholarly institutions in the United States, Israel, Europe, and Latin America. Items that the Library of Congress received from JCR bear a unique bookplate marking their special provenance. In addition - through federal transfers that occurred before JCR began its distributions in 1949 - the Library received approximately 150 Hebraic volumes bearing the stamps of anti-Semitic Nazi organizations that are also likely to have been seized by the Nazis from Jewish victims of the Holocaust. In recognition of the special provenance of these books, the Library of Congress has created a virtual library aggregating both collections in its online catalog under the "Holocaust-Era Judaic Heritage Library." The full bibliographic record for each work includes a provenance note indicating the specific acquisition source and accession date for each title." ${ }^{26}$

25. "Agreements Negotiated by the Commission in the Public and Private Sectors," PCHA. 26. As of May 2004, 1,326 titles are in the virtual library.The Holocaust-Era Judaic Heritage Library, Hebraic Section of the Library of Congress.Available online at http://www.loc.gov/rr/ amed/hs/hscoll.html. See Grunberger,"Special Challenges in Dealing with Looted Book Collections." 
The Baltimore Hebrew University (BHU) also was a recipient of looted materials: 4,552 items, including books and newspapers. ${ }^{27}$ Like the Library of Congress, BHU's Meyerhoff Library created a virtual library, and continues to identify books bearing the JCR bookplate and other European book markings. Furthermore, institutions such as the Library of Congress and BHU have acknowledged how certain items were acquired and are providing guidance to other libraries in similar situations.

During its four years of operation, the Offenbach Depot handled more than three million items. About half belonged to German institutions, including 700,000 books to the Prussian State Library in Berlin. More than 377,000 items were returned to France. But despite the tireless efforts of the MFA\&A at Offenbach, hundreds of books were never recovered and returned to their rightful owners. The Offenbach Depot undertook the largest book restitution program ever created, and numbers alone do not clearly represent the intensity of the restitution efforts by the MFA\&A. In his diary, Bencowitz poignantly described the program's humanitarian and cultural dimensions:

I would walk into the loose document room to take a look at the things there and find it impossible to tear myself away from the fascinating piles of letters, folders, and little personal bundles ... I would come to a box of books ... like scattered sheep into one fold-books from a library which once had been in some distant town in Poland, or an extinct Yeshiva. There was something sad and mournful about these volumes ... as if they were whispering a tale of yearning and hope long since obliterated ... How difficult it is to look at the contents of the depot with the detachment of someone evaluating property or with the impersonal viewpoint of scholarly evaluation. ${ }^{28}$

27. As of May 2004, 195 titles are in the virtual library. Jewish Cultural Reconstruction Books, The Joseph Meyerhoff Library, Baltimore Hebrew University.Available online at http://www. bhu.edu/meyerhoff/.

28. Poste, "Books Go Home from the Wars," 1703. 


\title{
ACRL Rare Books and Manuscripts Section
}

\section{(RBMS) and Asian, African and Middle Eastern}

\author{
Section (AAMES)
}

Sunday, June 26, 2005

1:30 - 3:30 p.m.

Collecting World Cultures: African, Asian,

Caribbean, and Native American Materials in

Chicago Institutions

Cultural collections - treasure troves for scholars or cultural property of the groups they document? How do librarians balance these and other ethical and collection management challenges? Chicago institutions have amassed extensive collections of diverse materials representing cultures from the New World (Native American, Caribbean), Asia, and Africa. Librarians and scholars will discuss challenges such as possible cultural appropriation, opportunities for multifaceted use by native communities, and difficulties presented by linguistic diversity.

Speakers: Nancy Cirillo, Associate Professor of Comparative Literature, University of Illinois, Chicago; Brian Hosmer, Director of the D'Arcy McNickle Center for American Indian History, Newberry Library; James Nye, Bibliographer for Southern Asia, University of Chicago; Nancy R. John, Assistant University Librarian, University of Illinois at Chicago; David L. Easterbrook, George \& Mary LeCron Foster Curator, Melville J. Herskovits Library of African Studies, Northwestern University. Co-sponsored by LES and the American Indian Librarians Association (AILA). 